\title{
Recent and Current Educational Research with and in Developing Countries by Researchers from Britain
}

\author{
Keith Watson
}

\section{Introduction}

Interest in education in developing countries on the part of academics and administrators from the United Kingdom has a long history. Numerous official reports on education in individual colonial territories date back well into the 19th century, while policy documents and memoranda for discussion in the Colonial Office began to appear in the 1920s and 1930s [Whitehead 1982; Watson 1982]. More detailed discussion papers for individual countries appeared prior to the independence of these countries from the late 1950 s onwards. Whereas in the past much research was undertaken with a 'from us to them' approach, more recently there have been far more collaborative ventures. Most of the research referred to in this article, though not all, will refer to the collaborative type.

To produce a survey, however general, of the recent and current educational research being undertaken by UK researchers in, or with, developing countries is fraught with difficulties. For one thing, much of the research is individual and is thus, by its very nature, diffuse. For another it is impossible to track down all those engaged in research projects, since some of these, while having a specifically educationl interest, may not necessarily be working in education departments. Inevitably, therefore, there will be omissions, for which this author, at least, apologises. Another point for apology is that a survey can be little more than a superficial account, pointing readers in the direction of where they might find more detailed reports of the work being undertaken.

ln order to provide a degree of coherence, therefore, this paper seeks to examine themes or areas of research and related research, rather than to list individual departments and researchers and to report on their activities.

\section{Areas of Research}

Examination reform, qualifications and job selection have for more than a decade exercised the attention of a number of researchers, especially from the Institute of Development Studies (1DS) at the University of Sussex. Ron Dore's book, The Diploma Disease [1976] intensified the general public's awareness of the problem and the multi-country research project he initiated has now issued a number of reports by several of his colleagues, along with a winding-up book [Oxenham 1984]. 1t also had the distinction of being made into a Japanese TV series and a film. At the instance of the 1LO's Jobs and Skills Programme for Africa (JASPA), the research was extended in a much modified form to 16 countries of Africa - eight anglophone and eight francophone.

Growing out of the original 'Diploma Disease' research is a six-country project on 'Students Learning Orientations', coordinated by Angela Little, also of the IDS. 1t is included as one of the cases of collaborative research in this volume [see Little]. A second outgrowth is still being put together: its focus is the effect of different lengths and qualities of schooling on trainability.

Alongside the research has been Somerset's 'applied' work with the Kenya Examinations Council on reforming the examination for the Certificate of Primary Education. The fruits of that experience are now finding wider relevance in Indonesia and Nepal [Somerset 1983].

Community education and the teacher's role in rural and community development is another fruitful area of research that has long fascinated British academics as well as colonial officials, community development officers and politicians. There has been a wealth of reports on this aspect of educational development carried out since the 1920s. Some of these were outlined by this author in his study of teachers as community developers in Thailand and Iran [Watson 1982, 1983]. The area continues to attract wide attention. One of the most substantial and valuable surveys of recent times was that undertaken by Margaret Sinclair and Kevin Lillis from IDS, and 
funded by the Overseas Development Administration [1980].

The Department of Education in Developing Countries at the University of London Institute of Education has also had an interest in community education for many years since Batten first wrote his School and Community in the Tropics [1959] and Houghton and Tregear produced their theoretical study in 1969. This has recently been updated by Linda Dove on behalf of the UNESCO Institute of Education in Hamburg. Dove has also made a special study of rural teachers in Bangladesh [Dove 1980] and, while working for the UNESCO Regional Centre in Dhaka, she has studied overall educational performance in Bangladesh [Dove 1983]. Jon Lauglo has also been involved in studying rural teachers in community education from a historical perspective [Lauglo 1982]. From Bristol University, Bob Thompson has recently surveyed the scene as to what lessons can be learned from the experience of the past decade [Thompson 1983].

More specific geographical surveys of community education have also, been undertaken recently. Staff at Reading University and in the Agricultural Extension and Rural Development Centre (AERDC) especially have made studies of developments in South East Asia, especially in Indonesia, Thailand and the Philippines [Martin 1984; Watson 1983]. Funding for these studies has come from the Overseas Development Administration and the University. Kenneth King's (Edinburgh) survey of community education in Africa [King 1976] is still a classic on that part of the developing world. Graham Vulliamy's work (University of York) on community education in Papua New Guinea was part of a collaborative venture with the PNG Ministry of Education, the British Council and the Nuffield Foundation [Vulliamy 1983].

One of the most recent surveys of the school and the community has been Beatrice Avalos' (University College, Cardiff collaborative study in Latin America. Funded by the International Development Research Centre (IDRC) in Ottawa from 1981-83, the project involved individuals and centres in Chile, Bolivia, Colombia and Venezuela. Its purpose was to examine those characteristics, especially of and within a community, that might be linked with school success or failure in the first four years of primary school in poor urban and poor rural contexts. Although it is hoped that a final report on the whole project will be published by IDRC in late 1984, an account of the Colombian developments is already available [Tezanos et al 1983]. There have been a number of interesting side effects. The research methodology was unknown in the participant centres, so that a part of the project became a training exercise in research methodology in the four Latin American countries involved. The long term effects have been to establish a qualitative research network in Latin America, sponsored by IDRC. Already an ethnography of Colombian teacher training institutions has been produced.

Rural migration patterns Closely associated with the effects of poverty in rural communities and the place of schooling in encouraging rural-urban migration has been the work undertaken by Rosemary and David Preston (University of Leeds) in Highland Ecuador. The project, funded by the Overseas Development Administration and the Ministries of Agriculture and Education in Ecuador, was a collaborative BritishEcuadorian venture. It was designed to analyse the social and economic consequences of emigration from rural communities. A related piece of work, funded jointly by the former Social Science Research Council and the International Project for the Development of the South in Loja, Ecuador, and the Ecuadorian Ministry of Education, sought to examine popular attitudes to education, the mismatch between curriculum and rural needs and the impact of a small amount of primary schooling on rural migration. Since the purpose of schooling in Highland Ecuador is to prepare pupils for life in the modern, urban, capitalist sector, the educational process keeps peasant families at the periphery in a state of subservience and dependence [Preston 1979, 1981, 1984]. A new collaborative project is being designed to examine the impact of the expansion and diversification of educational provision on the livelihood strategies of farming hoseholds in both Ecuador and Indonesia.

Population migration and its impact on access to education and school mapping, especially in rural Africa, has been a research interest of Bill Gould (University of Liverpool) for much of the past decade. A geographer by training, Gould's work, often in collaboration with the World Bank, has had a profound impact on much educational policy making in Africa and on the more important issues of distance-decay and the location of schools [for example, Gould 1978].

Education's impact on rural development, as opposed to rural migration, has been part of the ongoing work and training of the AERDC at Reading University for almost 20 years, long before rural development became fashionable in international aid fora. Reports on these programmes are too numerous to mention but can be obtained from the AERDC Documentation Centre.

Educational innovation and transfer, especially in the area of curriculum development, also attracts much attention. In the case of the University of London 
Institute of Education (Comparative Education Department) the concern has been for a more theoretical discussion about the place of educational dependency, especially in the context of East Africa (McLean) and Latin America, most notably Brazil (Cowan). McLean has offered several critiques on educational dependency [for example, 1983, 1984], the most recent appearing in the proceedings of the British Comparative and International Education Society's Conference on Dependence and Interdependence in Education [Watson 1984]. In this same volume Lewin and Little of Sussex reject the application of dependency theory to examination reform in Sri Lanka as a result of their joint study in that country [Little and Lewin 1982, 1984]. Neelu Sancheti has reached similar conclusions in her study of the development of Indian Institutes of Management, funded by the Ford Foundation [Sancheti 1984]. Bob Cowan is about to embark on a large, 12-nation collaborative study, involving writers from both the North and the South, in assessing how far the problems of educational transfer lead to dependency on other nations. Kenneth King (Edinburgh) has examined the question of educational transfer in the context of Kenya and Tanzania (King 1983). Perhaps the most thorough review of the literature on educational innovation and transfer has been produced by Paul Hurst (EDC Department, ULIE) [Hurst 1983].

The most important aspect of educational change which has exercised the minds of British researchers is that of curriculum development. Kevin Lillis (EDC Department, ULIE) has made a special study of curriculum innovation in Kenya [Lillis 1982]. Lewin's work (Sussex) on science curriculum development in Sri Lanka and Malaysia has been very well documented [Lewin 1975, 1980, 1981, 1983]. He is currently trying to gain funding for an exploratory study of science education and science teacher training in China as an extension of these studies. Keith Watson's (Reading) concern was for the pressures and policies of introducing the Scottish Integrated Science programme in modified form into lower secondary schools in Malaysia [Watson 1980]. Hugh Hawes' (EDC Department, ULIE) work on curriculum development and planning curriculum change in the African context has been an ongoing, and frequently collaborative, area of research for more than a decade [Hawes 1976, 1979] while Linda Dove has, on behalf of the Commonwealth Secretariat, made a study of curriculum development projects in the New Commonwealth countries [Dove 1980a, 1983].

The two most pressing aspects of curriculum innovation and educational innovation that are currently being analysed are 1) the implications of financial and economic recession, and 2) the development of educational courses with a direct bearing on vocational or technical training. In the first category are studies undertaken at Sussex by Lewin, Little and Colclough [1983], and Colclough, Lewin and Oxenham [1983]. These have all looked at the implications of economic recession for educational expenditure in general terms. Lewin, however, looked at the planning implications of economic recession in four specific countries - Sri Lanka, Thailand, Malaysia and Singapore, when he presented a paper at the annual conference of the Development Studies Association in 1983 [Lewin 1983a]. The curriculum implications of economic recession and financial stringency are examined in a paper delivered at the Association of Teachers of Overseas Education in Birmingham in April 1984 [Lewin 1984].

Kenneth King (University of Edinburgh) has been concerned with similar implications in Tanzania. Originally funded by CIDA and working in collaboration with colleagues from the Department of Education at the University of Dar-es-Salaam (most notably Professor I. Omari and Mr H. Mosha), King has been exploring the implications of economic constraints on educational quality, particularly in Tanzanian primary schools. As yet there are few tangible pieces of written evidence, though Kenneth King has produced a short paper on 'The end of education for self-reliance in Tanzania?'. He has also just begun a collaborative programme with a number of Kenyan academics, funded by IDRC, the Rockefeller Foundation, the University of Edinburgh Centre of African Studies and the Hayter Foundation, looking into secondary school quality in Kenya and the implications for the employment market.

The costings of different secondary school streams in relation to the learning outcomes and initial earnings of school leavers in Tanzania and Colombia have been the purpose of a joint World Bank/Tanzanian/ Colombian project recently completed, but not yet published. Entitled the DISCUS project - Diversified Secondary Curricula Study project - it is mentioned here because of the involvement of a key British researcher in the field, Keith Hinchcliffe (University of East Anglia).

The second area of ongoing research, concerned with introducing technical/vocational type courses into schools could prove to be a very fruitful field of research. Already Kevin Lillis (EDC Department, ULIE) and Des Hogan (University of Sussex) have collaborated and written about vocational education and training in Sri Lanka and Kenya and both have written a wider review of the literature [Lillis and Hogan 1981, 1983].

Jon Lauglo (EDC Department, ULIE) is currently directing a project on behalf of SIDA, evaluating the 
Swedish assistance to the development of industrial eduation in Kenyan general secondary schools. The study is truly collaborative in so far as it involves Swedes, Kenyans, and other British researchers [for instance, Lillis and Chris Cumming (Moray House)]. It is unlikely to be completed before the spring of 1986 . While the initiative for the project originated in Sweden, the project should benefit both the Kenyan and other governments. The purpose of the study is to analyse the implementation of industrial education in schools, examination results, learning outcomes and employment possibilities.

At a different level, and in a different context, Kenneth King has recently embarked upon an ODA funded project, to analyse the needs of Kenya for scientific and technological manpower, and the educational and training implications of these needs. Reversing the North-South trend, David Knox (Cardiff) has written several papers on linking education with production and has tried to show what can be learnt from developments in Botswana [for example, Knox 1982].

In service education of teachers Inevitably one of the most crucial aspects of any educational development, possibly the most crucial aspect, is that of the education of teachers. With the rapid expansion of school systems throughout most of the developing countries during the 1960s and 1970s it proved impossible to provide sufficient trained teachers to operate the system. A consequent concern has been to improve the quality of the teaching force through in service training. How effective some of this in service training has been is of great interest to a number of British academics, who, by the very enormity of the task, have had to work in teams.

The Commonwealth Secretariat in the early 1980s commissioned a survey of the in service education of teachers in the Commonwealth. While Bob Thompson (University of Bristol) coordinated the research survey, which involved a study of the relevant literature, a number of specific visits and some directed inquiries - taking Asia as his field, others, for examples, Ray Bolam (Australia, Canada and New Zealand), Jeremy Greenland (Africa), Roy Parker (small island communities) and Peter Taylor (UK) divided up the globe between them. The findings of this study appeared in 1982 [Thompson 1982].

A more specifically collaborative and research based study was the enormous INSET Africa Project, a study of the in service training of primary school teachers in 13 African countries during 1980-81. Jeremy Greenland (then of Bristol, now of EDC Department, ULIE) directed the project, which was funded by ODA, and linked the Bristol Centre for Overseas Studies with 13 African Ministries of
Education and 15 African universities. The results of the study have been published [Greenland 1983] as has the report of one of the dissemination conferences which was funded by the German Foundation for Education Research (DSE) [Bude and Greenland 1983]. This was held in Zimbabwe in April 1982 and covered developments in East, Central and Southern Africa. The report of the second conference, held in Gambia in September 1983, and covering West Africa, has yet to be published.

There have been a number of other smaller scale researches into the effectiveness of teacher education. Beatrice Avalos undertook a pilot study of in service teacher education in Thailand during 1983, which was undertaken with Dr Malee Nitsaisook of the Thai Ministry of Education, Department of Teacher Education, and which was funded jointly by IDRC and the Thai Ministry of Education; Michael Eraut (Sussex) has been involved in developing in service teacher education programmes in Singapore; and Don Taylor (Manchester) has explored the cost effectiveness of upgrading teachers in Southern Africa through the use of distance teaching [Taylor 1983].

Small countries On the periphery of much of the mainstream of educational research, but of vital importance to many of the smaller countries of the Commonwealth, is the study of the mismatch between education and the labour market in small island communities. Work in this field is of great interest to the Commonwealth Secretariat, since so many countries of the Commonwealth are small island communities in the Caribbean, the Indian Ocean and the Pacific Region, and a number of small scale projects have been funded by the Secretariat. Of those British scholars most active in this field are Colin Brock (Hull), Susan Durston (Leeds) and Roy Parker (Bristol).

Evaluation of projects should be built in to any educational development programme. As is well known this is not necessarily the case. Increasingly, however, aid agencies in the North are wishing to evaluate their aid programmes. The work being undertaken by Jon Lauglo and his colleagues in Kenya and already alluded to earlier, fits into this category. For the past four years, Peter Williams (EDC Department, ULIE) has been evaluating ODA's Technical Cooperation Training Programme on behalf of ODA. The report is expected to be published during 1984. Kenneth King is coordinating, but Beatrice Avalos and others are involved in, the IDRC's Research Review and Advisory Group. This is a small body designed to bring together scholars in both the North and the South to assist in reviewing and analysing educational research and conditions affecting this research. One aspect of the review body is that of evaluating projects. 
Training Administrators The 1980 World Bank Education Sector Policy Paper referred to maladministration and poor planning and management as major constraints on educational development in all countries, but particularly in countries of the South. While there are a number of national, regional and international initiatives that have been, or are being, developed to help alleviate the shortage of trained personnel, concern has been expressed about training methods and strategies, and about the training materials being used. As a result of discussions with ODA, Paul Hurst (EDC Department, ULIE) is being funded to coordinate a three-year research and development project on Training Third World Educational Administrators - Methods and Materials. Based at the London Institute of Education, it is a collaborative venture insofar as a network of institutions (42) and individuals in 21 different countries has been formed to assess the nature of existing training provision, its future potential and the training materials likely to be needed. The initial research phase is now completed. The next phases include materials production and materials evaluation. The long term implications of this piece of research could have a profound impact on future educational development and planning and the project has already aroused considerable interest.

\section{Conclusions}

Inevitably this cursory overview has omitted both individuals and areas of research (for instance, planning, developments in socialist societies, the politics of education and multicultural societies). However, a survey of this nature does highlight several interesting points.

1 Education, especially within the context of the Third World countries, is far more than formal schooling and higher education. Even within the formal sector there are enormous areas to be studied - curriculum content, examinations, teaching methods, costs, etc - but none can be studied in isolation from their particular political or socioeconomic context. Some scholars have therefore felt happier concentrating on individual countries or case studies; others have looked thematically, crossculturally. Drawing conclusions from either case studies or cross-cultural studies is not easy and the scope for further and related research in many of the areas outlined above is therefore enormous.

2 Another point is that some researchers become identified specifically with one count ry or geographical region. It does mean that key individuals have great insights into certain countries or regions and should be called upon to help in any interdisciplinary or international developments that may take place. It also means, however, that it is sometimes very difficult to break away from an image or mould and enter into new pastures, as Bob Thompson found when he tried to break away from his 'Africa' image.

3 There are a small number of dedicated and key researchers scattered around the UK. Only in London and Sussex can it be truly said that there are teams of cooperating researchers. Elsewhere, research work can be lonely and may be going on in isolation from similar work elsewhere. Opportunities such as meetings of the Development Studies Association which bring research workers together are therefore greatly to be welcomed.

4 One final observation is how few interdisciplinary teams there are in operation - not just within the field of education, in which educationists work in conjunction with researchers from other disciplines. Since the early 1970s it has been widely acknowledged that education's role in development is only viable, if it is within an integrated development framework. Comparative educationists have for long argued that comparative education can only be adequately undertaken with an interdisciplinary team, as the IEA surveys highlighted.

My concluding plea, therefore, is this. By all means let us have greater collaboration between researchers, and between researchers in different countries, but above all let educationists work closely alongside economists, social anthropologists, political scientists, etc. In this way their small contributions might be of much greater significance and might have a much greater impact.

\section{References and bibliography}

Batten, T. R., 1959, The School and Community in the Tropics, Oxford University Press, Oxford

Blaug, M., 1973, Education and the Employment Problem in Developing Countries, ILO, Geneva

Bude, U. and J. Greenland, (ed), 1983, In-service Education and Training of Primary School Teachers in Anglophone Africa, Nomos Verlagsgesellschaft, Baden Baden

Colclough, C., K. Lewin and J. Oxenham, 1983, 'UK bilateral assistance to primary education, paper for ODA advisers

Dore, R., 1976, The Diploma Disease, Allen and Unwin, London

Dove, L., 1980, 'The role of the community school in rural transformation in developing countries', Comparative Education, vol 16 no 1, pp67-79

-1980a, Curriculum Reforms in Secondary Schools: a Commonuealth survey, Commonwealth Secretariat, London

-1983, 'Curriculum development in the New Commonwealt h', International Journal of Educational Development, vol 3 no 2 , ppl39-47 
-1983a, 'Educational policy in Bangladesh 1978-81: promise and performance in political perspective', Comparative Education, vol 19 no 1, pp73-88

Gould, W. S., 1978, 'Guidelines for school location planning, Staff Working Paper no 308, World Bank, Washington

Greenland, J. (ed), 1983, The In-service Training of Primary School Teachers in English-Speaking Africa, Macmillan, London

Hawes, H. W. R., 1976, 'Locally based educational research and curriculum development in developing countries the teacher's role', IIEP Occasional Paper no 40, UNESCO, Paris

- 1979, Curriculum and Reality in African Primary Schools, Longman, London

Hurst, P., 1983, 'Implementing educational change: a critical review of the literature, EDC Occasional Paper no 5, ULIE, London

King, K. (ed), 1976, Education and Community in Africa, University of Edinburgh

-1983, 'Educational transfer in Kenya and Tanzania', Compare, vol 13 no $1, \mathrm{pp} 81-8$

Knox, D. and S. Castles, 1982, 'Education with production: learning from the Third World', International Journal of Educational Development, vol 2 no 1, ppl-14

Lauglo, J., 1982, 'Rural primary school teachers as potential community leaders? Contrasting historical cases in western countries*, Comparative Education, vol 18 no 3, pp233-56

Lewin, K., 1975, 'Science education in Malaysia and Sri Lanka', Discussion Paper no 74, IDS, Sussex

- 1980, 'Curriculum renewal and examination reform: a case study from Malaysia', IDS Bulletin, vol 11 no 2, IDS, Sussex

-1981, 'Qualification and Selection in Educational Systems', summary report, IDS, Sussex

- 1983, 'Selection and curriculum reform: two case studies of science curriculum development from Malaysia and Sri Lanka', Bristol University conference paper

-1983a, 'The political economy of educational planning in recession', DSA Annual Conference, Sussex

- 1984, 'Quality in question: curriculum issues in education and development, paper presented to the ATOE Conference, Birmingham, 2-4 April

Lillis, K. and D. Hogan, 1981, Attempts to Diversify Secondary School Curricula in Developing Countries: a literature review and some additional hypoiheses concerning causes of failure, Centre for Educational Technology, Sussex

-1983, 'Dilemmas of diversification: problems associated with vocational education in developing countries'

Little, A. W., 1980, 'The development of the child's understanding of the causes of success and failure: case studies from England and Sri Lanka', IDS Development Research Register no 4

- 1982, as above, unpublished DPhil thesis, University of Sussex -and Lewin, K., 1982, 'Examination reform in Sri Lanka: dependent development or evolutionary change?', paper given to the Comparative and International Education Society, Stanford, California

- 1982a, 'Examination reform and educational change in Sri Lanka 1972-82: modernisation or dependent underdevelopment?', Discussion Paper no 180, IDS, Sussex

- 1984, as above (1982a) in K. Watson (ed), Dependence and Interdependence in Education: International Perspectives, Croom Helm, London

Martin, C., 1984, 'Community school or the community's school?', Compare, vol 14 no 1, pp85-106

Mclean, M., 1983, 'Educational dependency: a critique', Compare, vol 13 no 1, pp25-42

Oxenham, J., 1980, 'Employers and qualifications', IDS Bulletin, vol 11 no 2, IDS, Sussex

-1980a, The Paper Qualificaition Syndrome and the Unemployment of School Leavers, JASPA/ILO

-(ed), 1980b, 'Selection for employment versus education?', IDS Bulletin, vol 11 no 2, IDS, Sussex

- 1982, The Paper Qualification Syndrome and the Unemployment of School Leavers: a sub-regional study of eight Anglophone African countries, ILO, Geneva

-1984, Education Vs. Qualifications?', Allen and Unwin, London

Preston, R. A., et al, 1979, 'Rural emigration and agricultural development in highland Ecuador', School of Geography, Leeds University

- 1981, Education and migration in Highland Ecuador, unpublished $\mathrm{PhD}$ thesis, Leeds University

-1984, 'Dependency perspectives on the impact of education on family livelihood strategies in rural areas of Andean America' in K. Watson (ed), Dependence and Interdependence in Education: international perspectives, Croom Helm, London

Sancheti, N., 1984, 'Institutional transfer and educational dependency - an Indian case study', in Watson, ibid

Simmons, J. (ed), 1980, The Education Dilemma: policy issues facing educational planners in developing countries, Pergamon, Oxford

Somerset, A., 1983, 'Secondary Education, Selection Examinations and University Recruitment in Indonesia: some key issues', Commissioned Study 3, IDS, Sussex

Taylor, D. C., 1983, 'The cost-effectiveness of teacher upgrading by distance teaching in Southern Africa', International Journal of Educational Development, vol 3 no 1 , pp 19-32

Tezanos, A. de, E. Romero and G. Munoz, 1983, Escuela y communidad, un problema de sentido, Universidad Pedagogica Nacional, Bogota

Thompson, A. R. (ed), 1982, In-service Education of Teachers in the Commonu'ealth, Commonwealth Secretariat, London

-1983 , 'Community education in the 1980s: what can we learn from experience?', International Journal of Educational Development, vol 3 no 1, pp3-18 
Watson, K., 1983, 'Rural primary school teachers as change agents in the Third World: three case studies', International Journal of Educational Development, vol 3 no 1, pp47-60

Whitehead, C., 1982, 'Education in British colonial dependencies 1919-1939: a reappraisal' in K. Watson (ed), Education in the Third World, op cit
Vulliamy, G., 1983, 'Secondary schools community extension project (SSCEP), Papua New Guinea in K. Lillis (ed), School and Community in Developing Countries, Association of Teachers of Education Overseas

Watson, K. (ed), 1982, Education in the Third World, Croom Helm, London

- 1980, 'Influences and constraints on curriculum development in the Third World', Canadian and Intemational Education, vol 9 no 2, pp28-42 